\title{
Multiple Evolutionary Origins of Magnetotaxis in Bacteria
}

\author{
Edward F. DeLong, ${ }^{\star}$ Richard B. Frankel, Dennis A. Bazylinski $\dagger$
}

Magnetosomes are intracellular, iron-rich, membrane-enclosed magnetic particles that allow magnetotactic bacteria to orient in the earth's geomagnetic field as they swim. The magnetosomes of most magnetotactic bacteria contain iron oxide particles, but some magnetotactic species contain iron sulfide particles instead. Phylogenetic analyses of small subunit ribosomal RNA sequences showed that all known magnetotactic bacteria of the iron oxide type are associated with the $\alpha$ subgroup of the Proteobacteria in the domain Bacteria. In contrast, uncultured magnetotactic bacteria of the iron sulfide type are specifically related to the dissimilatory sulfate-reducing bacteria within the $\delta$ subdivision of the Proteobacteria. These findings indicate a polyphyletic origin for magnetotactic bacteria and suggest that magnetotaxis based on iron oxides and iron sulfides evolved independently.

Magnetotaxis in bacteria (1) is the result of a permanent magnetic dipole moment that causes a cell to be oriented in the earth's geomagnetic field as it swims (2). The magnetic dipole moment is caused by

$\overline{\text { E. F. DeLong, Department of Biology, University of }}$ California, Santa Barbara, CA 93106.

R. B. Frankel, Department of Physics, California Poly technic State University, San Luis Obispo, CA 93407 D. A. Bazylinski, Department of Anaerobıc Microbioogy, Virginia Polytechnic Institute and State University Blacksburg, VA 24061

*To whom correspondence should be addressed. †Present address: Department of Chemistry and Chemical Engıneering, Stevens Institute of Technology, Castle Point on the Hudson, Hoboken, NJ 07030. the presence of magnetosomes (3), intracellular, iron-rich, membrane-enclosed magnetic particles. In most magnetotactic bacteria, the particles consist of the ferrimagnetic iron oxide magnetite $\left(\mathrm{Fe}_{3} \mathrm{O}_{4}\right)$ (4-8). However, some magnetotactic bacteria collected from sulfidic, brackish-to-marine aquatic habitats have recently been found to contain iron sulfide particles $(9,10)$, including ferrimagnetic greigite $\left(\mathrm{Fe}_{3} \mathrm{~S}_{4}\right)(9$, $11,12)$ and nonmagnetic pyrite $\left(\mathrm{FeS}_{2}\right)(9$, 11). Although magnetotactic bacteria of both the iron oxide and iron sulfide types are frequently found in the same habitats, they grow in discrete locations, as indicated 
A

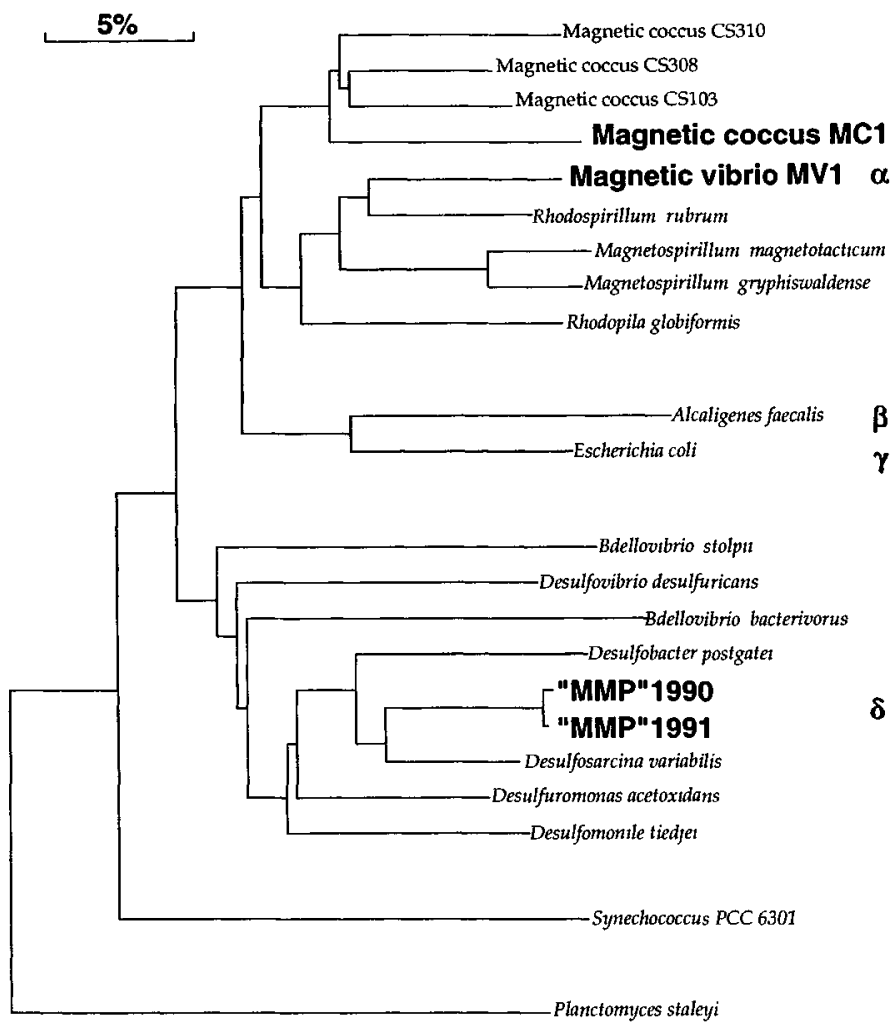

Fig. 1. Phylogenetic relations of iron oxide- and iron sulfide-type magnetotactic bacteria. Synechococcus PCC 6301 and Planctomyces staleyi are included as outgroups to the Proteobacterial lineage. (A) Evolutionary distances were estimated with the correction of Jukes and Cantor (27) from 630 aligned, moderately to highly conserved nucleotide positions. Phylogenetic tree topology was inferred with the least squares distancematrix analyses software of Olsen (28) obtained from the ribosomal RNA database project (29). Scale bar represents five fixed mutations per 100-
B

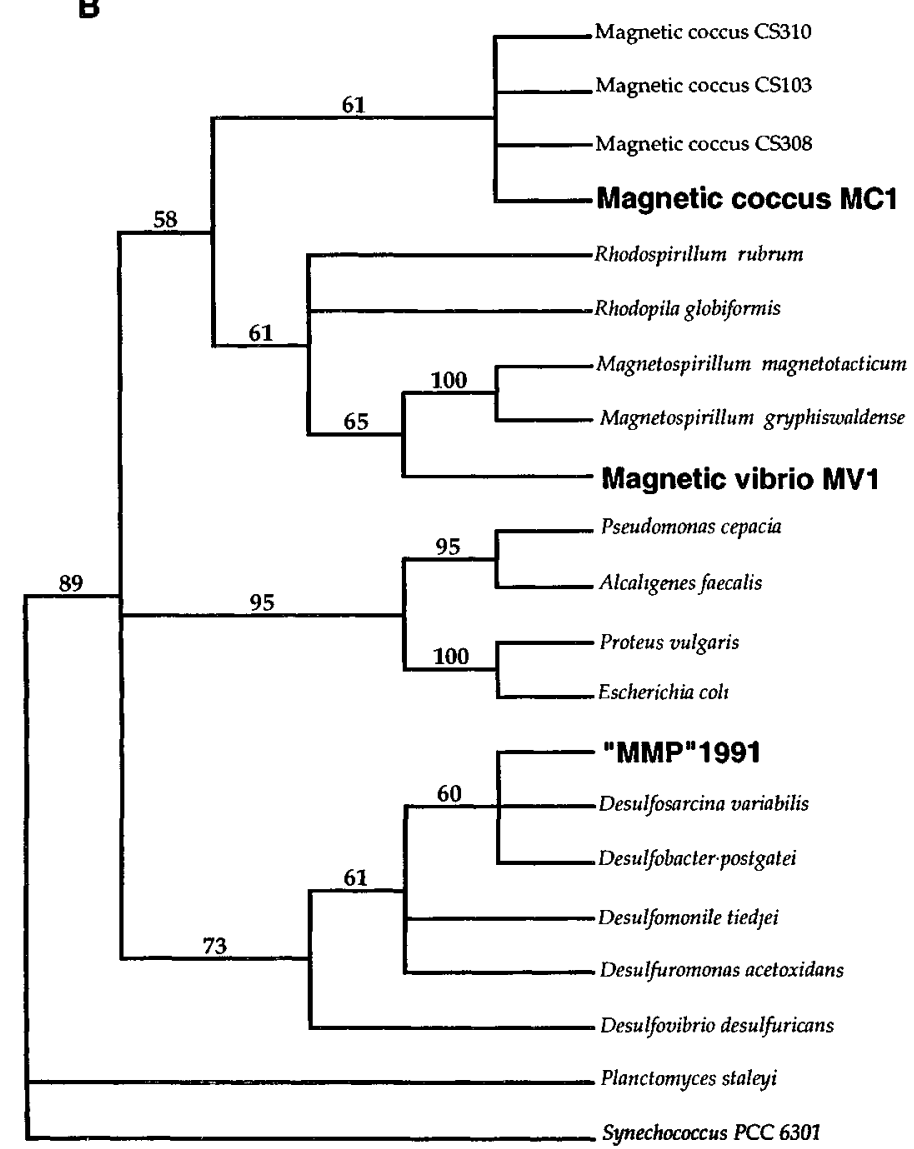

nucleotide sequence positions. (B) Results of maximum-parsimony analysis (PAUP version 3.0s) and bootstrap resampling of the dataset (3032). The tree topology summarizes the results obtained from 100 trees generated from 100 individual bootstrap resamplings of the dataset. Values indicate the percentage of bootstrap resamplings that yielded the branching pattern to the right of that value in the majority-rule consensus tree. Sequences (33) obtained in this study are in bold type. by vertical oxygen and sulfide concentration gradients (13). However, iron sulfidetype magnetotactic bacteria have not been cultivated to date, and their relation to iron oxide-type magnetotactic bacteria has not been described.

Magnetotactic bacteria were collected from sulfidic, brackish-to-marine sediment and water from various coastal sites in New England with the use of a modified racetrack technique (14). A magnetotactic, many-celled prokaryote (MMP) $(15,16)$ was collected in large numbers, but could not be cultured. Transmission electron microscopy and energy-dispersive $\mathrm{x}$-ray analysis of the magnetosomes in this organism showed that the magnetosomes contained only iron and sulfur, consistent with the presence of greigite and pyrite (9). Three magnetotactic cell types were also isolated and cultured for comparative purposes. These included the first coccoid strain to be cultured axenically, designated MC-1 (17), and two vibrioid strains, designated MV-1 (8) and MV-2 (17). Transmission electron micros- copy and electron diffraction have determined that strains MC- 1 and MV-2 contain particles of magnetite (18).

Nucleic acids were purified from magnetotactic bacteria, and the small subunit ribosomal RNA genes (ssu rRNA) were amplified, cloned, and sequenced (19). Distance-matrix (Fig. 1A) and maximum-patsimony analyses (Fig. 1B) of the ssu rRNA sequences of the cultured, iron oxide-type magnetotactic bacteria indicated that these bacteria were members of the $\alpha$ subdivision of the Proteobacteria (20) in the domain Bacteria. The rRNA sequences of the magnetite-containing vibrioid strains MV-1 and MV-2 were identical and fell within the $\alpha$ subdivision. However, these strains were not closely related to any previously characterized magnetotactic species, including the magnetotactic spirilla Magnetospirillum (formerly Aquaspirillum) magnetotacticum (21) and M. gryphiswaldense (22) or to several uncultured magnetotactic cocci (23). Unrestricted rRNA sequence similarity values between strain $M V-1$ and other $\alpha$
Proteobacteria ranged from 0.83 to 0.87 . The magnetite-containing coccus, strain $\mathrm{MC}-1$, was more peripherally related to the $\alpha$ Proteobacteria group. Ribosomal RNA sequence similarities between strain MC-1 and its closest relatives, a group of different, uncultured, freshwater magnetotactic cocci (23) (CS103, CS308, and CS310; Fig. 1), ranged from 0.85 to 0.87 . Secondary structural analyses support the inclusion of the magnetite-containing magnetotactic bacteria within the $\alpha$ subdivision of the Proteobacteria. For example, strain MC-1 contained a 3-base pair stem between nucleotide positions 184 to 193 (Escherichia coli numbering) and a shortened helix between nucleotide positions 198 to 219 . These combined features distinguish members of the $\alpha$ subdivision from those of the $\beta, \gamma$, and $\delta$ subdivisions of the Proteobacteria (24).

Phylogenetic analyses of the ssu rRNA sequence of the MMP indicated the affiliation of this bacterium with the $\delta$ subdivision of the Proteobacteria (Fig. 1). This 
Fig. 2. (A) Phase contrast and (B) epifluorescent micrographs of the same viewing field of a magnetic enrichment containing the MMP. Cells were fixed in formalin and hybridized (34) simultaneously with a Texas red-labeled (Molecular Probes, Eugene, Oregon), eubacterial-specific oligonucleotide probe (25) and a fluorescein-labeled, MMP-specific probe. (B) Fluorescence micrograph with epifluorescence filters specific for Texas red excitation and emission spectra. (C) Fluorescence micrograph with epifluorescence filters specific for fluorescein excitation and emission spectra. The sequence of the MMP-specific probe was GGA CTC ACC CTT AAA CGG. This sequence is complementary to nucleotide positions 218 to 235 (E. coli numbering) of the MMP rRNA

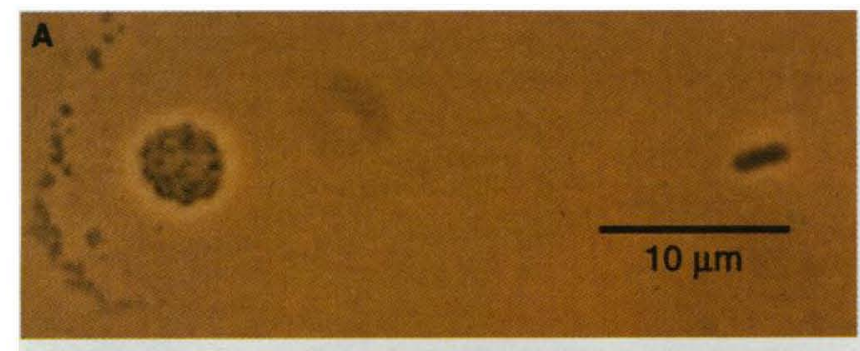

B
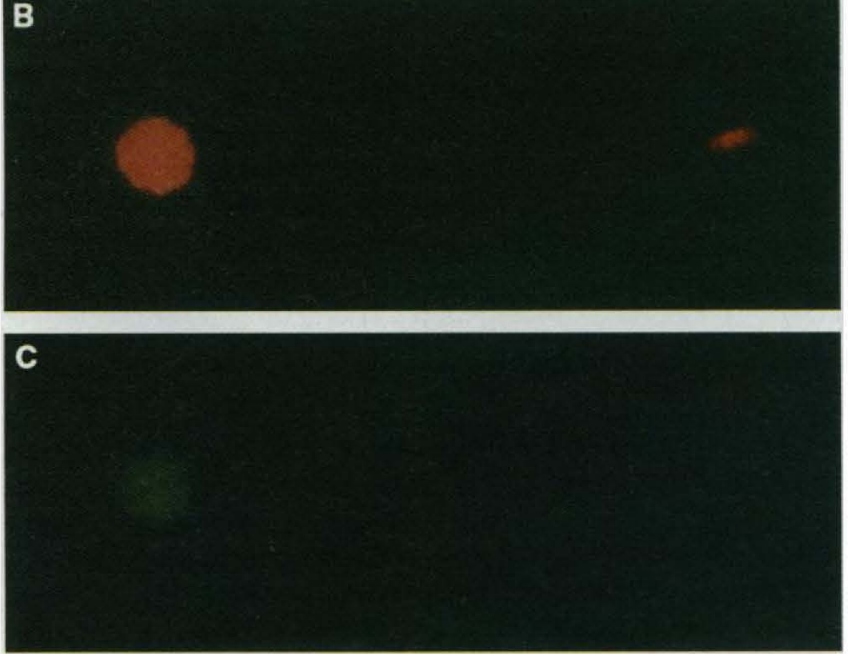

4. R. B. Frankel, R. P. Blakemore, R. S. Wolfe, Science 203, 1355 (1979)

5. K. M. Towe and T. T. Moench, Earth Planet Sci. Lett. 52, 213 (1981).

6. T. Matsuda, J. Endo, N. Osakabe, A. Tonomura, T Arii, Nature 302, 411 (1983)

$\rightarrow$ S. Mann, N. H. C. Sparks, R. P. Blakemore, Proc. R. Soc. London Ser. B 231, 469 (1987)

8. D. A. Bazylinski, R. B. Frankel, H. W. Jannasch, Nature 334, 518 (1988)

9. S. Mann, N. H. C. Sparks, R. B. Frankel, D. A Bazylinski, H. W. Jannasch, ibid. 343, 258 (1990).

10. M. Farina, D. M. S. Esquivel, H. G. P. Lins de Barros, ibid., p. 256

11. D. A. Bazylinski, R. B. Frankel, A. J. Garratt-Reed, S. Mann, in Iron Biominerals, R. B. Frankel and R. P. Blakemore, Eds. (Plenum, New York, 1990), pp. 239-255.

12. B. R. Heywood, D. A. Bazylinski, A. J. GarrattReed, S. Mann, R. B. Frankel, Naturwissenschaften 77,536 (1990).

13. J. F. Stolz, in Iron and Manganese Biomineralization Processes in Contemporary Environments, $\mathbf{R}$ W. Fitzpatrick and H. C. W. Skinner, Eds. (CatenaVerlag, Cremlingen-Destedt, Germany, in press)

14. R. S. Wolfe, R. K. Thauer, N. Pfennig, Fed. Eur. Microbiol. Soc. Microbiol. Ecol. 45, 31 (1987).

15. M. Farina, H. G. P. Lins de Barros, D. M. S. Esquivel, J. Danon, Biol. Cell 48, 85 (1983)

16. F. G. Rodgers et al., Arch. Microbiol. 154, 18 (1990).

17. Strains MC-1 and MV-2 were isolated from water collected from the Pettaquamscutt Estuary in Rhode Island.

18. F. C. Meldrum, B. R. Heywood, S. Mann, R. B Frankel, D. A. Bazylinski, in preparation.

19. Cells of the MMP were lysed and the nucleic acids extracted as previously described [E. F. DeLong, Proc. Natl. Acad. Sci. U.S.A. 89, 5685 (1992)]. A $1.5-\mathrm{kb}$ region of the ssu rRNA gene was amplified by PCR [R K Saiki et al Science 239,487 (1988)] with the use of oligonucleotide primers broadly specific for the eubacterial rRNA gene [D. broadly specific for the eubacterial rRNA gene [D.
$\mathrm{J}$. Lane, in Nucleic Acid Techniques in Bacterial Systematics, E. Stackebrandt and M. Goodfellow. Eds. (Wiley, New York, 1991), pp. 115-175]. Amplified ssu rRNA gene products were cloned into a commercially prepared vector PCR 1000 (Invitrogen, San Diego, CA), and individual clones (Invitrogen, San Diego, CA), and individual clones small-scale plasmid preparations. The cloned rRNA inserts were sequenced by the dideoxychain termination method with the use of Sequenase 2 (US. Biochemical Cleveland $\mathrm{OH}$ ) and rRNA-targette
es, after es, after ammonium acetate precipitation, the double-stranded PCR product was directly sequenced. Amplification of the rRNA genes of the pure cultures was performed as above except that one of the primers was biotinylated. After amplification, the biotinylated strand was purified am. Hultion, the biotinylated strand was Uhlen, Nucleic Acids Res. 17, 4937 (1989)] with the use of avidin-coated magnetic beads (Dynal, Inc., Great Neck, NY) and sequenced directly.

20. E. Stackebrandt, R. G. E. Murray, H. G. Truper, Int. J. Syst. Bacteriol. 38, 321 (1988)

21. P. A. Eden, T. M. Schmidt, R. P. Blakemore, N. R. Pace, ibid. 41, 324 (1991).

22. K. H. Schleifer et al., Syst. Appl. Microbiol. 14, 379 (1991).

23. S. Spring, R. Amann, W. Ludwig, K. H. Schleifer N. Petersen, ibid. 15, 116 (1992).

24. C. R. Woese, Microbiol. Rev. 51, 221 (1987)

25. D. A. Stahl and R. Amann, in Nucleic Acid Techniques in Bacterial Systematics, E. Stackebrand and M. Goodfellow, Eds. (Wiley, New York, 1991) pp. 205-248.

26. G. A. Zavarzin, E. Stackebrandt, R. G. E. Murray, Can. J. Microbiol. 37, 1 (1991).

27. T. H. Jukes and C. R. Cantor, in Mammalian Protein Metabolism, H. N. Monro, Ed. (Academic Press, New York, 1969), pp. 21-132.

2. R. B. Frankel, Annu Rev. Biophys. Bioeng. 13, 85 (1984).

3. D. L. Balkwill, D. Maratea, R. P. Blakemore, J. Bacteriol. 141, 1399 (1980).
28. G. J Olsen, Methods Enzymol. 164, 793 (1988).

29. G. J. Olsen, R. Overbeek, N. Larsen, C. R. Woese, sion of the Proteobacteria. In contrast, the
iron sulfide-type MMP is affiliated with the the cell in the geomagnetic field by using different magnetic minerals.

\section{REFERENCES AND NOTES}

\begin{abstract}
amined in this study and elsewhere $(21-23)$ are specifically affiliated with the $\alpha$ subdivi-

The type of magnetosome mineral appears to reflect phylogenetic affiliation. All contained intact and accessible target rRNA. However, only the MMP cells bound the
\end{abstract}


Nucleic Acids Res. 19, 4817 (1991).

30. J. Felsenstein, Evolution 39, 783 (1985)

31. D. L. Swofford and G. J. Olsen, in Molecular Systematics, D. M. Hillis and C. Moritz, Eds. (Sinauer, Sunderland, MA, 1990), pp. 411-501.

32. D. L. Swofford, PAUP version 3.0s (Illinois Natural History Survey, Champaign, IL, 1989).

33. Sequences have been submitted to GenBank and carry accession numbers LO6455, MV-1 LO6456, MC-1; LO658, MMP 1990; and LO6457, MMP 1991

34. E. F. DeLong, G. S. Wickham, N. R. Pace, Science 243, 1360 (1989)
35. We thank P. A. Eden, T. M. Schmidt, R. P. Blakemore, J. McN. Sieburth, and N. R. Pace for sharing unpublished information and for helpful discussions; D. G. Franks for technical assistance; and J. F. Stolz for critically reading this manuscript. This work was supported by the U.S. Office of Naval Research (ONR) grant N00014-91 J-1290; E.F.D. was the recipient of an ONR Young Investigator Award N00014-90-J-1917. D.A.B is also supported by National Science Foundation grant MCB-9117694. 